\title{
Brasil 3 x 1 Uruguai, semifinal da Copa de 70 (um relato-ensaio retrospectivo)
}

\author{
Brazil 3 x 1 Uruguay, Semifinal of the 1970 World Cup \\ (A Retrospective Essay-report)
}

\begin{abstract}
Teodoro Rennó Assunção
Universidade Federal de Minas Gerais, Belo Horizonte/MG, Brasil Doutor em Histoire et Civilisations, École des Hautes Études en Sciences Sociales, França teorenno@letras.ufmg.br
\end{abstract}

RESumo: Como o título bem indica, este artigo é uma mistura de relato e ensaio interpretativo sobre a partida semifinal da Copa do Mundo de futebol de 1970 entre a seleção brasileira e a uruguaia, cujo resultado foi a vitória do Brasil por 3 a 1. Mas ele é também a tentativa de restituir detalhadamente, por meio de uma partida decisiva e difícil, não somente a maneira de jogar de uma equipe habilidosa e criativa no meio de campo e no ataque (dando destaque a um jogador taticamente importante, mas às vezes menos lembrado do que Pelé, Jairzinho ou Gérson, que é o Tostão, e à sua destreza ímpar nos passes), mas de restituir também o modo como no futebol os momentos ou as situações de uma partida podem mudar repentina e imprevisivelmente, demandando assim dos jogadores (além do preparo físico e da essencial vontade de ganhar) uma atenção à variação dos momentos e às chances únicas e decisivas.

PalaVRaS-CHAVE: Brasil 3 x 1 Uruguai; Semifinal; Copa de 1970; Relato-ensaio; Tostão.

ABSTRACT: As the title rightly indicates, this article is a mixture of an account and an interpretive essay on the 1970 FIFA World Cup semifinal match between the Brazilian and the Uruguayan national teams, the result of which was Brazil's 3-1 victory. It is also an attempt to restore in detail, by means of a decisive and difficult match, not only the way of a skillful and creative team playing in the midfield and in the attack (highlighting a tactically important player, but sometimes less remembered than Pelé, Jairzinho or Gérson, who is Tostão, and his unique skill in passing), but also to restore the way in football the moments or situations of a match can change suddenly and unpredictably, thus demanding from players (in addition to physical fitness and the essential desire to win) attention to the variation of moments and to the unique and decisive chances.

KeYwords: Brazil 3 x 1 Uruguay; Semifinal; 1970 World Cup; Essay-report; Tostão. 
pro Tostão (vivíssimo e bem-pensante cronista)

\author{
A bola $[\ldots]$ \\ que, como bicho, é mister \\ (mais que bicho, como mulher) \\ usar com malícia e atenção, \\ dando aos pés astúcias de mão. \\ João Cabral de Melo Neto, \\ "O futebol brasileiro evocado da Europa".
}

Ainda que seja possível dizer que um núcleo de memória do próprio jogo visto (em preto e branco) com nove anos de idade numa televisão pequena e com imagem certamente bem menos nítida do que a atual de "alta definição" ("HD, High Definition") tenha se conservado, misturado certamente com os inúmeros VTs de compactos e dos gols (já em cores), primeiro em retrospectivas da Copa do Mundo (de futebol) de 1970 no próprio cinema na época, e depois na televisão não sei quantas vezes, o que vou tentar modestamente fazer aqui é a narração resumida de uma experiência recente de ter assistido o VT desse jogo inteiro em cores e em HD na TV (o que não é possível fazer com um mero recurso ao YouTube, por causa dos direitos da FIFA sobre as imagens do jogo inteiro), já sabendo do resultado do jogo e conhecendo bem os quatro gols e alguns lances memoráveis, numa grande retrospectiva da íntegra dos seis jogos do Brasil nessa Copa de 70 no Sportv1 (da Globosat), comemorando um exato meio século de existência de cada jogo memorável (exatamente no seu dia) no mês de junho de 1970 e agora de 2020 (às 23:30 de cada um desses dias, horário um pouco ingrato), ${ }^{1}$ para preencher de algum modo o insuportável vazio de jogos de futebol brasileiro ao vivo nesta quarentena

\footnotetext{
${ }^{1}$ Um detalhe bem importante desses VTs dos seis jogos inteiros do Brasil na Copa de 1970 (cada qual de uma hora e meia e mais alguns poucos acréscimos, pois na época juiz algum estendia muito os dois tempos de 45 minutos de um jogo) é que apenas o visual filmado estava sendo retransmitido, enquanto tanto a locução (obviamente sem grande importância, como no rádio, senão para uma correta identificação dos jogadores, técnicos, juiz e bandeirinhas) quanto os comentários não eram os de quem os haviam feito há 50 anos atrás (mesmo que os sons da partida então acontecendo tivessem sido conservados), mas de locutores e comentaristas atuais, que (como eu próprio) já sabiam de todos os resultados dessa Copa e muito dificilmente conseguiriam fingir bem uma emoção qualquer de quem poderia ser surpreendido por um outro curso dos eventos em uma série temporal sucessiva e irreversível que compõe o evento maior total de um jogo de futebol. Apenas pra lembrar aquele que era 0 locutor brasileiro de TV mais conhecido então (o Geraldo José de Almeida), vou citar agora, em sua homenagem, o modo como ele descrevia com precisão um gol que acabava de ser feito (por seu efeito imediato no resultado mesmo da partida): "Olha lá, olha lá, olha lá no placarrrrrr..." (arrastando bem o "r" final dessa palavra).
} 
bem estendida devido à terrível pandemia do coronavírus num Brasil inteiramente desgovernado e já tendo se tornado o $2^{2}$ país em todo mundo com o maior número de infectados e de mortes devidas a esse novo vírus.

Curiosamente eu sempre guardei alguma memória (confirmada agora pelos depoimentos dos jogadores) de que esse jogo era visto então pela imprensa como muito perigoso pro Brasil devido ao desastre da final da Copa de 1950, em pleno Maracanã (o famoso "Maracanazo"), quando o Brasil, com um time considerado bem melhor tecnicamente, perdeu de 2 a 1 pro Uruguai, em dois vacilos fatais (sobretudo o último, no gol de Giggia, pra abominável desonra do goleiro Barbosa) e talvez também por alguma vergonhosa falta de virilidade ou "raça" (à qual se contrapunha o heroísmo macho, e indiferente ao imenso público brasileiro que lotava o estádio, do capitão uruguaio Obdúlio Varela), algo que sempre foi também decisivo no futebol. ${ }^{2}$ Mas, de um ponto de vista objetivo, segundo o mero regulamento, então bem conhecido de todos, esse jogo era perigoso ou possivelmente fatal simplesmente porque era (depois da fase classificatória dos grupos, em que o Brasil ficou em 1ํ lugar com três vitórias, e já como no caso das quartas de final na vitória de 4 a 2 contra o Peru) uma partida única e eliminatória (ou de "mata-mata"), ${ }^{3}$ em que todas as chances estavam sendo apostadas de uma

\footnotetext{
${ }^{2}$ No entanto, diferentemente do jogo contra a Inglaterra, que foi ao meio-dia (obrigando o Brasil a se antecipar na madrugada pra ficar com o melhor vestiário), o jogo contra o Uruguai foi num horário bem mais ameno do verão mexicano: às 16 horas ou 4 da tarde, dispensando o Brasil de qualquer iniciativa nesse sentido e lhe permitindo um concentrar-se apenas no adversário. Apenas como uma curiosidade (de que em algum remoto dia eu já tinha ouvido falar) vale registrar o que Carlos Alberto diz sobre Pelé no vestiário antes de qualquer partida começar: "O Pelé dormia no vestiário, o Pelé tinha esse hábito. Em qualquer jogo, ele ia pro vestiário, pegava um saco de roupa, que servia de travesseiro, ia lá num cantinho, num banco, tirava lá um soninho. Ele apagava, tem gente que tem essa facilidade. E acordava com tudo, né?" (TORRES. Fui com tudo, cheguei na passada certa, com a certeza de que iria fazer o gol).

${ }^{3}$ Mas caberia lembrar que objetivamente também o time da Seleção Uruguaia, composto com uma base de jogadores do Nacional e do Peñarol, era formado por alguns jogadores do Peñarol (como o goleiro Mazurkiewicz, o zagueiro Forlan e o meio campo Pedro Rocha que felizmente não jogou contra o Brasil) que já haviam sido não só campeões nacionais, mas também da Libertadores e mesmo do Mundial de Clubes em 1966, assim como do Nacional (com alguns jogadores que estavam na Seleção de 1970, como Luis Cubilla) que seria campeão da Libertadores em 1971, e cabendo ainda lembrar que fazia parte, por exemplo, da tradição do futebol uruguaio ter tido um time, o Peñarol, que foi bicampeão das duas primeiras Libertadores da América em 1960 (sendo que neste ano, no jogo de volta contra o Olímpia do Paraguai, em Assunção, depois de ter vencido em Montevidéu por 1 a 0 , o Peñarol empatou em 1 a 1 com o Olímpia, com um gol de Cubilla aos 38 minutos do 20 tempo), e em 1961 (ganhando do Palmeiras por 1 a 0 em Montevidéu e empatando em 1 a 1 em São Paulo, sendo que Cubilla, apesar de não ter marcado gol, jogou ambos os jogos) e foi também campeão mundial de clubes em 1961 (novamente com Cubilla jogando) e ainda disputou as finais da Libertadores com o Santos também campeão do mundo em 1962 (ainda uma vez com Cubilla
} 
vez por todas (no que, paradoxalmente, algo de cada instante único e irreversível da própria vida humana de cada indivíduo, mesmo que não necessariamente o da morte, estaria sendo também de algum modo representado), dando ao espectador do jogo um medo, um frisson e uma graça únicos, sobretudo porque o time brasileiro estava indo muito bem (quatro brilhantes vitórias) e seria uma tristeza que tudo fosse desperdiçado pra disputar um medíocre e jamais compensatório $3^{\text {o }}$ lugar (como, por exemplo, na Copa de 1978), o que na hora H parece revelar bem que no futebol também a vitória ou o resultado final é muito (ou talvez o mais) importante.

Estranhamente, o que é bem próprio do futebol, o Brasil parece ter se assustado um pouco no primeiro tempo com a marcação cerrada e violenta dos uruguaios (que tinham até então a melhor defesa da Copa) e não conseguia acertar bem as sequências de jogadas do meio de campo pra frente (ou às vezes apenas na finalização), apesar de também não sofrer propriamente maiores perigos de um ataque uruguaio que era, no fim das contas, como o próprio meio de campo uruguaio no sentido da armação de jogadas, bem insosso e medíocre.

Mas agora, enfim, vou dizer algo que só o rever tranquilo de todo o jogo pôde permitir, em contraste com o depoimento retrospectivo de cinco jogadores (Carlos Alberto, Clodoaldo, Gérson, Tostão e Piazza, mas sobretudo o do Gérson) que acentuou um certo "apagão" do Brasil no 1ำ tempo, como se não tivesse jogado "nada":4 o Brasil, com um toque de bola bem melhor (apesar do padrão do Uruguai não ser também de todo ruim), criava muito mais jogadas de ataque do que o Uruguai (ainda que fosse um jogo muito interrompido devido às muitas jogadas violentas e faltosas), e logo aos 19 minutos foi surpreendido numa jogada em que o famoso ponta direita ou atacante Luis Cubilla (e não Cubillas com "s", como é o nome do craque peruano que fez o $2^{\circ}$ gol do Peru no jogo anterior do Brasil), depois de um erro bisonho de passe do nosso bruto beque Brito ${ }^{5}$ e uma recepção

jogando). "Não jogamos, não tinha explicação [para o primeiro tempo]. Sentamos lá, discutimos, argumentamos, chegamos à seguinte conclusão: 'Nada'." (GÉRSON. Como é que você vai admitir que o Pelé jogue 45 minutos mal?).

4 "Não jogamos, não tinha explicação [para o primeiro tempo]. Sentamos lá, discutimos, argumentamos, chegamos à seguinte conclusão: 'Nada'." (GÉRSON. Como é que você vai admitir que o Pelé jogue 45 minutos mal?).

${ }^{5}$ No entanto, num primeiro lance de perigo para o Uruguai, foi Everaldo quem cabeceou meio mal, cortando um lançamento pelo alto pra esquerda, e a bola sobrou pro atacante Fontes que chutou de primeira bem forte e rasteiro no canto direito, mas o goleiro Félix estava bem colocado e pulou rápido pra baixo pegando firme a bola e sem dar rebote (o perigoso "bater roupa"). 
de bola tranquila e repasse imediato e preciso de Morales, recebeu a bola livre e meio sem ângulo já dentro da grande área, mas aparentemente sem grande perigo, e num chute não tão forte (e parecendo um cruzamento que tivesse dado errado, mesmo que nenhum outro atacante estivesse propriamente chegando pra conferir), mas muito bem colocado se realmente intencional, pegou o nosso às vezes "feliz" e "dorminhoco" Félix no contrapé e foi morrer no outro e esquerdo cantinho interior do gol (enquanto o Piazza chegava já meio atrasado e sem poder fazer nada), causando uma vibração intensa dos uruguaios e um certo desespero completamente desconcertado ("como é que isso pode estar acontecendo conosco agora?") dos brasileiros.

Como tive a impressão de ter visto (neste VT privilegiado) um pouco mal esse gol de Luis Cubilla, passando a desconfiar então de que ele pudesse ter tentado o gol diretamente (e não indireta e equivocadamente), como também o seu olhar pra dentro da pequena área (na hora do lance) parecia indicar bem, além do fato (só agora evidente pra mim) de que nenhum atacante uruguaio estava chegando à grande área pra finalizar o que teria sido um mero cruzamento pra área, voltei a ver o lance mais de uma vez em compactos no YouTube e passei enfim, com um pouco mais de justiça à realidade dos fatos, a considerar que esse foi um gol de muita técnica e malícia deste atacante uruguaio (pois ele também apostou inteligente e calculadamente que esse goleiro - por "coincidência" meio dado a vacilos - não estaria esperando um improvável chute direto e sem ângulo e seria pego de surpresa numa decisiva fração de segundo), ou seja e forçando um pouco o oximoro na escolha insólita do adjetivo: um "discreto golaço". ${ }^{6}$

Mas não houve propriamente "apagão" nenhum, pois o Brasil, apesar de estar perdendo por causa deste gol apenas à primeira vista meio fantasma (ou "ubaldino", como os mineiros poderão reconhecer), continuou atacando e mantendo o controle do jogo (em termos de domínio de bola e habilidade, como a

\footnotetext{
${ }^{6}$ Se considerarmos que esse Cubilla, então já meio gordinho e com 30 anos de idade e que tinha fama de ser meio irritante para os beques adversários, já tinha sido 5 vezes campeão uruguaio, 2 vezes campeão da Libertadores em 1960 e 1961 e campeão mundial de clubes em 1961 pelo Peñarol, e voltaria a ser campeão uruguaio e da Libertadores em 1971 pelo Nacional, o grande rival do Peñarol (e isso sem considerar que ele seria ainda duas vezes campeão da Libertadores como técnico), teríamos, sem dúvida, uma figura inquestionável de um herói que foi um dos maiores jogadores da história do futebol uruguaio, algo de que só agora, com a facilidade de consulta imediata de bons sites sobre futebol no Google, estou enfim me dando conta (mas antes tarde do que nunca...).
} 
Seleção Holandesa de 74 e o bom Barcelona depois), tendo tido várias chances de gol e mesmo o que hoje seria talvez considerado um pênalti no Pelé, cabendo aí, portanto, a observação - não secundária ou menor - de que, para o padrão de arbitragem de hoje (ou do que é considerado falta grave ou passível de cartão amarelo, que só então aparecia timidamente pela primeira vez nas Copas, ou inaceitável e merecendo expulsão com o cartão vermelho, também uma novidade), o Uruguai dificilmente poderia ter saído como um quase vitorioso naquele 1o tempo da semifinal da Copa de 70, sendo que, antes do dramático gol de empate, o Brasil ainda teve três chances mais ou menos claras de gol, além do já citado possível pênalti em Pelé (segundo foi reclamado então pelos brasileiros, mesmo que hoje possamos ter alguma dúvida), num jogo em que os jogadores brasileiros estavam sendo "caçados" com violência pelos uruguaios e correndo assim o risco de "arregarem" e ficarem com o moral meio baixo.

$\mathrm{Na}$ primeira chance, trocando a bola tranquilamente no campo do adversário, Rivelino passa pro Clodoaldo que (como médio volante bom de bola e que não tinha medo de arriscar) chuta de longe, mas com perigo, a bola passando meio alto (mas não acima do limite vertical do gol) ao lado da trave esquerda de um goleiro que, caso ela tivesse ido mais pra dentro do gol, talvez não a alcançasse (pois é tudo muito rápido, o que o VT em câmera lenta costuma falsear...). Na segunda, é o Gérson quem, muito marcado no primeiro tempo, dá um passe ou cruzo preciso e suave, na borda de dentro da grande área, pro Pelé que cabeceia com algum perigo para o chão ao lado da trave direita. Na terceira, numa falta perigosa no ângulo de fora direito da grande área, é Rivelino (grande batedor de faltas, como o $1^{10}$ gol contra a Tchecoslováquia tinha provado bem) quem cobra a falta com curva, a bola indo na direção certa no alto do gol, mas um pouco no meio demais, facilitando uma boa defesa do grande goleiro Mazurkiewicz, o famoso Mazurka (que depois dessa Copa jogaria dois anos com algum variável brilho no Atlético Mineiro, assim como o lateral esquerdo Cincunegui, algo de que nenhum torcedor mineiro mais velho, como eu mesmo, jamais vai se esquecer).

Mas o problema é que o Brasil, obstaculizado por uma defesa uruguaia compacta (com desarmes precisos, mas também muitos lances violentos e desleais de falta), não conseguia fazer o gol, aumentando a tensão e criando um possível 
risco pro $2^{\circ}$ tempo (nos pedaços de VTs com narração dos locutores e comentários dos comentaristas da época, o lúcido João Saldanha "aparece" falando que falta justamente uma postura mais agressiva e direta no ataque brasileiro...). Mas também, como sabemos explicitamente agora (com os depoimentos dos cinco jogadores e principalmente o do Gérson), o Gérson, muito marcado, propôs pro Carlos Alberto e o Clodoaldo que ele (Gérson) invertesse de posição com o Clodoaldo, pra que esse ficasse mais livre e tivesse mais chances de chegar tabelando no ataque com os (por sua função primeira) atacantes Pelé, Jairzinho e Tostão. Essa inversão inteligente (e que hoje sabemos ter acontecido a partir de uma "sacada" do Gérson, que era quem armava o jogo todo e não estava conseguindo jogar direito, sem que pra isso fosse preciso esperar o Zagalo dar o seu aval), já indicada de algum modo na primeira chance perigosa de gol que o Brasil teve depois do gol do Uruguai, acabou sendo decisiva no dramático gol de empate do Brasil, no último minuto do $1^{\circ}$ tempo, quando Everaldo, na esquerda do campo, toca pra Clodoaldo que, por sua vez, toca pra Tostão bem no canto esquerdo do campo (e não pro Rivelino, o "ponta esquerda" ou meio de campo, que não sabemos bem onde está) e este, pressentindo e já vendo a avançada meio inesperada de Clodoaldo pelo ataque em direção à grande área adversária, toca muito precisamente pra ele (Clodoaldo), no ante-pé do zagueiro uruguaio que chegava também correndo pra tentar marcar o Clodoaldo, de modo que a bola quica uma vez maciamente na grama e, quando ela sobe de leve, Clodoaldo pega de bate-pronto, preciso e forte, e manda do outro lado (o direito) do gol, impedindo qualquer reação do goleiro, num golaço inesquecível, "em cima da mosquita", empatando o jogo e "salvando", no finalzinho do $1^{\text {o }}$ tempo, o Brasil. ${ }^{7}$

\footnotetext{
${ }^{7}$ Caberia aqui uma observação sobre o modo como não só antes das partidas, mas também nos intervalos, estavam consoladoramente ausentes as tradicionais propagandas de cervejas ou de carros (voltadas pra um público majoritário presumivelmente masculino), o que não impedia o mimetismo ao menos de um compacto rápido dos "melhores lances" do $1^{\circ}$ tempo, mas com os comentários diferenciados (porque já cientes do que se passou no $2^{\circ}$ tempo e do resultado final da partida) de atuais comentaristas de futebol na TV (aqueles mais ou menos conhecidos da Globosat e do Sportv, incluindo os de arbitragem: Júnior, Casagrande, Ricardinho, Roger Flores, Petkovic, Paulo Vinícius Coelho, Lédio Carmona, Maurício Noriega, e pra arbitragem Arnaldo Cezar Coelho e Sandro Meira Ricci, além de locutores como Cléber Machado, Luís Carlos Júnior, Jota Júnior e Milton Leite). Dos locutores e comentadores de 1970 que a frequentação do YouTube me permitiu ressuscitar eu lembraria como locutor o Valter Abrahão e como comentaristas o Ruy Porto (de que eu tinha me esquecido totalmente) e o João Saldanha (que eu também lia no Jornal do Brasil que meus pais assinavam na época);
} 
Pelo que representava essa semifinal eliminatória e irreversível, em que o Brasil estava perdendo (apesar de jogando melhor) e arriscando de uma vez por todas naquela Copa a própria vida, esse gol decisivo (de que ninguém que acompanhou essa Copa vai jamais se esquecer) parece, a seu modo, demonstrar ainda uma vez a evidência de que o futebol é fundamentalmente um jogo de equipe (são 11 contra 11 e, além da importância do entrosamento dos 11 de cada lado, qualquer falha maior e inesperada de qualquer jogador podendo afetar todos do seu time e, inversa e complementarmente, todos do time adversário), em que o empenho técnico (ou de habilidade ou talento), tático (de boa percepção da posição ou função no grupo) e também de alma ou vontade de ganhar (a chamada "raça") são todos conjuntamente (já que, na performance mesma, eles são inseparáveis e igualmente importantes) decisivos, sendo aqui um bizarro centroavante deslocado pela esquerda (Tostão) quem, como uma espécie de meio de campo esperto (função habitualmente exercida pelo Rivelino), dá um passe macio e preciso (como saber qual a intuição permite que isso aconteça, obviamente sem nenhuma garantia de que vá dar certo, como aliás tudo o mais de realmente importante nessa vida humana e mortal?) pra um médio volante chegar correndo como um atacante e, depois de um quique da bola, pegar bem chapado e mandar direto e à meia altura pro canto inverso do gol, vencendo inapelavelmente o goleiro, golaço "milagroso" que só retrospectivamente pode parecer ao espectador um evento que deveria de qualquer modo ter acontecido. ${ }^{8}$

Uma outra observação cabível agora (pra quem está "simplesmente" assistindo um jogo de futebol e, apesar de já sabendo o resultado, não tem nenhum compromisso prévio com uma pretensa "verdade" consagrada), antes da narração de um resumo do $2^{\text {o }}$ tempo dessa semifinal da Copa de 70, e segundo um comentário (obviamente não desprezível, mas também não necessariamente de

já as crônicas de Nelson Rodrigues n'O Globo eu só lia quando estava de férias na casa dos meus avós maternos em Itajubá.

${ }^{8} \mathrm{E}$ o que é mais curioso é exatamente o fato de que justamente a incerteza ou a possibilidade, aberta no então presente, de que esse gol não tivesse acontecido (ou acontecido de uma outra maneira) é o que traz uma emoção viva mesmo retrospectivamente ao evento, que, porém, como outras "obras de arte" performáticas da cultura de massa, pode também se desgastar e acabar se banalizando triste e fatalmente por uma repetição insistente e estúpida. Sobre a indeterminação fundamental do futuro (ou contingência) como dimensão temporal característica não só de um jogo de futebol, mas de todo "agora" numa vida humana até o último e derradeiro evento (o apito final ou a morte), ver o meu ensaio "Breve nota sobre o tempo trágico no futebol" (RENNÓ ASSUNÇÃO. Breve nota sobre o tempo trágico no futebol, p. 259-262). 
todo verdadeiro) do Gérson, é que o Pelé, o "rei" e grande craque dessa Copa (como aliás também outros grandes craques desse time em vários outros momentos das seis partidas e vitórias da campanha vitoriosa inquestionável dessa Seleção Brasileira), errou vários passes e chutes, em muitas jogadas bisonhas que, recortadas e justapostas em sequência (como o fazem hoje certos vídeos compactos no YouTube), parecem desmentir a imagem ou aura mitológica ("me engana que eu gosto...") do obviamente idealizado jogador de futebol perfeito (ou quase) e maior esportista do século XX. ${ }^{9}$

No entanto, seria preciso fazer também aí um derradeiro ajuste, segundo o mero bom senso, pois ainda nessa mesma partida, como sabemos bem, apesar de que ainda fosse errar um pouco, Pelé iria dar passes muito precisos e decisivos nos dois gols seguintes do Brasil e também (no finalzinho do jogo) um drible de corpo antológico em Mazurkiewicz e um chute final rasteiro muito bem dado que por pouco não entra, como se provando assim a relativa obviedade de que o mais importante não é não errar (algo em alguma medida inevitável num jogo coletivo complexo e de confronto como o futebol), mas estar ao máximo presente e participando bem ativamente das jogadas de modo a poder também acertar, encaminhando a jogada para o gol e servindo bem a um companheiro que vai concluí-la ou eventualmente a concluindo e fazendo ele mesmo o próprio gol.

Um bom exemplo disso é a primeira jogada de maior perigo do Brasil no $2^{\circ}$ tempo desse jogo, quando Pelé na intermediária ou começo do campo do adversário dribla um uruguaio e leva rápido a bola pro ataque, se livrando de outros que chegam por trás e, sozinho e cercado por uns cinco jogadores, dribla mais um adversário, pouco antes de chegar à grande área adversária, e ainda mais um, já na entrada ou quase divisória da grande área, e leva uma falta que se parece muito com um pênalti, pois ele cai flagrantemente já dentro da área do Uruguai, levando o Tostão a sinalizar pro juiz apontando a marca do pênalti, que, no entanto e corretamente, não foi dado pelo juiz que marcou apenas uma falta fora da grande área, apesar de bem coladinha à linha divisória. Ora, Pelé, como autor da jogada e

\footnotetext{
9 "Como é que você vai admitir que o Pelé jogue 45 minutos mal? De não ter uma tabela, um lançamento, uma entrada do Jair, uma chegada do Carlos Alberto, um chute a gol de fora da área... Como é que você vai admitir isso nessa seleção, que fez isso o tempo todo?" (GÉRSON. Como é que você vai admitir que o Pelé jogue 45 minutos mal?).
} 
já de um gol de falta nessa Copa no jogo contra a Romênia, fez questão de bater a falta e isolou bisonhamente a bola pra longe do gol bem à direita e acima do gol (como, aliás, ele voltaria a fazer bem grosseira e bizarramente duas vezes na final contra a Itália). Mas pouco depois, tendo Mazurkiewicz batido mal um tiro de meta, bem em cima de onde estava o Pelé na intermediária do campo do Uruguai, este pegou a bola de bate-pronto e chutou direto pro gol, acertando-o, mas um pouco no meio de mais, e quase pegando desprevenido o goleiro uruguaio, que acabou se recuperando e fazendo uma boa defesa. ${ }^{10}$

Caberia aqui também um breve parêntese pra lembrar uma cotovelada bem dada por Pelé num zagueiro uruguaio que entrou meio faltosamente nele, tendo Pelé (e o Brasil) tido a sorte de o juiz não tê-la visto e ter marcado, portanto, a falta do zagueiro uruguaio, o que hoje pode parecer até meio irônico, sendo que, como o jogo estava então empatado, caso o juiz a tivesse visto bem, ele poderia até mesmo ter expulsado o Pelé, levando a uma sequência da partida totalmente diferente da que aconteceu, o que obviamente faz parte apenas de um mundo imaginário e conjectural, mas que, por contraste, esclarece bem o quanto a realidade agora de uma vez por todas definida era também, no momento mesmo em que acontecia, apenas uma possibilidade. ${ }^{11}$

\footnotetext{
10 A reação de Pelé, passando a mão sobre a cabeça mais de uma vez e como se inconsolável, pôde ser interpretada também como se ele estivesse de novo quase fazendo um gol de longe, num chute de primeira e pegando o goleiro desprevenido, como contra a Tchecoslováquia, quando o jogo estava também 1 a 1 , mas o fato é que o primeiro lance, um chute por cima de antes do meio de campo (ainda no campo brasileiro), mesmo tendo ido pra fora, ainda que passando bem rente à trave direita e já encobrindo o goleiro, foi bem mais ousado e impressionante.

$11 \mathrm{O}$ inteligente comentarista Tostão não só descreve de um outro modo essa cotovelada, mas faz também uma observação curiosa e bem-humorada (no seu livro mais recente) e que vale a pena citar aqui na sua íntegra: "Quando o jogo estava 1 a 1, Pelé deu uma cotovelada no zagueiro do Uruguai, vista por todo mundo. Hoje, certamente seria expulso. Com um a menos, aumentariam muito as chances de o Uruguai vencer, e assim o Brasil seria eliminado, eu não estaria aqui contando essa história e o mundo não falaria tanto da seleção brasileira de 1970." (TOSTÃO. Tempos vividos, sonhados e perdidos: Um olhar sobre o futebol, p. 66). Se imaginássemos todos os lances principais dessa partida (e apenas os principais) com suas alternativas hipotéticas de realidade futura e todas as diferentes partidas possíveis que isso implicaria, seríamos levados a uma pletora inumerável e vertiginosa de hipotéticas realidades futuras, um curioso exemplo futebolístico possível para o fantástico mundo paralelo ou "labirinto no tempo" do borgiano "jardim dos caminhos que se bifurcam": "Em todas as ficções, cada vez que um homem se defronta com diversas alternativas, ele opta por uma e elimina as outras; na do quase inextricável Ts'ui Pen, ele opta - simultaneamente - por todas. Ele cria, assim, diversos futuros, diversos tempos, que também proliferam e se bifurcam." (BORGES. O jardim de veredas que se bifurcam, p. 531).
} 
Um pouco depois ainda, era Tostão quem, chegando perto da área adversária pela meia esquerda, dava um belo corte num defensor uruguaio, mas acabava chutando rasteiro e muito fraco no canto esquerdo do gol, permitindo uma defesa fácil do goleiro uruguaio. 0 próximo lance de perigo (e, dessa vez, fatal) do time brasileiro, que (como nos outros quatro jogos) já começava a mostrar um preparo físico bem superior ao do time adversário, ${ }^{12}$ foi com 30 minutos já passados uma jogada perfeita dos três atacantes mais avançados, que começa ainda no campo brasileiro com uma roubada de bola bem esperta de Jairzinho, que avança rápido com a bola e passa pro Pelé já bem no meio do campo, e este, marcado em cima por um uruguaio, dá de costas a bola pro Tostão, que por sua vez caminha rápido com ela já no campo do adversário e, antes que chegue um marcador uruguaio, dá um passe mais longo bem macio e preciso pro Jairzinho que então avançava correndo pela direita, mas olhando também pro Tostão que tinha ficado com a bola, de modo que ele pode esperar pra receber a bola (se voltando ligeiramente pra trás), enquanto o zagueiro vacila um pouco e não consegue cortála, pois ele está meio de costas se esforçando pra acompanhar o atacante brasileiro, e esse (o grande e matador Jairzinho) então a recebe e a coloca na frente bem rápido e, já dentro da área e um pouco antes da chegada do goleiro, dá um chute rasteiro preciso e forte no canto esquerdo do goleiro que é vencido inapelavelmente, a bola indo morrer na rede à esquerda pelo lado de dentro, no que também foi um golaço.

Caberia aqui uma observação sobre o modo como Jairzinho (diferentemente dos atuais jogadores evangélicos que comemoram agradecendo a Deus apontando o dedo indicador da mão direita pra cima), após o seu gol (e alguns outros seus nessa Copa) faz o sinal da cruz no peito e abaixa a cabeça, no que poderia ser interpretado como signo de humildade diante do imponderável instantâneo no futebol (segundo uma versão religiosa católica) que pode decidir se uma conclusão

\footnotetext{
12 Sabemos hoje também que o time levou um grande "esporro" ou bronca do Zagalo no vestiário na hora do intervalo, o que, sem dúvida, pode também ter mexido um pouco e bem oportunamente com o brio dos jogadores, já que um jogo de futebol se ganha com "raça" também. É o que podemos deduzir a partir do seguinte testemunho de Tostão: "Eu lembro também que, no vestiário, foi o dia em que eu vi o Zagalo mais bravo na minha vida. O Zagalo ficou possesso. Gritava, xingava, falava alto que o time tava apático, que o time não conseguia jogar. E gritando e tal. Eu acho que ele não deu nenhuma instrução tática, não. Foi aquela coisa do grito mesmo. E isso também ajuda. Todo mundo ficou assustado, né?" (TOSTÃO. Foi o dia em que eu vi o Zagalo mais bravo na minha vida, ele ficou possesso).
} 
vai ser ou não bem sucedida, resultando em gol. ${ }^{13}$ Numa cena marcante (porque a primeira e meio aziaga) da campanha vitoriosa do Brasil nessa Copa de 70, o atacante Petras da Tchecoslováquia, após fazer o $1^{\text {o }}$ gol do jogo contra o Brasil, fez também o sinal da cruz no peito, o que pareceu um pouco estranho vindo de um jogador de um país comunista.

Talvez coubesse aqui agora uma observação meio óbvia, em homenagem ao Tostão, que era então o meu ídolo total cruzeirense e que nesse jogo foi decisivo nos dois primeiros gols do Brasil (como tinha sido antes no único gol da difícil vitória contra a Inglaterra), ${ }^{14}$ de que no futebol, um jogo coletivo, tão importante quanto uma conclusão bem feita e que resulta em gol, é o passe derradeiro preciso pra quem recebe a bola pra finalizar (ou pra quem vai dar o último toque pro finalizador, como aconteceu no gol contra a Inglaterra), algo que eventualmente pode parecer mais ou menos fácil, como se fosse apenas o primeiro fundamento desse jogo com os pés, mas que por sua precisão às vezes milimétrica, envolvendo não só a direção e a altura da bola em movimento, mas também a força com que ela é tocada e a velocidade que ela adquire, e tudo isso num conjunto de relações espaciais dinâmicas entre onze jogadores se movimentando contra onze jogadores, pode vir a ser uma espécie de "obra de arte" viva da performance ludopédica, encantando tanto ou ainda mais do que o próprio gol.15

\footnotetext{
${ }^{13}$ No meu já citado ensaio "Breve nota sobre o tempo trágico no futebol", eu tentei justamente pensar o que teria sido uma versão teológica grega pra esse modo de intervenção da divindade em um evento decisivo e imprevisível numa disputa: "É figurado assim [na týkhe, o "acontecimento" ou "acaso"] aquilo que - sobretudo em uma situação de relativo equilíbrio das duas forças adversárias [...] - irrompe e consagra de um modo misterioso (e não apenas por seus méritos) o vencedor. Para o pensamento mais arcaico da llíada, o "evento" decisivo que surpreende é sempre figurado como a manifestação de um deus (ainda que o mortal não saiba bem qual deles), e a "glória", enquanto estrela momentânea da vitória ou kûdos [...], é pensada como uma graça inconstante e caprichosa concedida pela divindade." (RENNÓ ASSUNÇÃO. Breve nota sobre o tempo trágico no futebol, p. 261).

${ }^{14}$ Que o próprio Tostão, que depois se tornou um grande comentarista (oral e pela escrita) de futebol, saiba bem disso é algo que não deveria de modo algum nos surpreender, tal como está bem indicado em seu já citado livro mais recente: "Dei, nesse jogo, os dois melhores passes da minha carreira, pela precisão, pela dificuldade e pela importância. E ainda dei um terceiro, para Pelé, por trás do zagueiro, que fez o mais belo 'quase gol' da história." (TOSTÃO. Tempos vividos, sonhados e perdidos: um olhar sobre o futebol, p. 66).

${ }^{15}$ Sobre a importância do passe preciso e rápido (ou seja: no tempo certo), o mais das vezes um toque de primeira (ou, no máximo, dois toques), Tostão, que na Seleção de 1970 se tornou antes um passador ou "facilitador" (o que, no Cruzeiro da segunda metade dos anos 1960, era geralmente feito pelo Evaldo) para dois atacantes mais agressivos e finalizadores que eram Jairzinho e Pelé, disse o seguinte em entrevista ao jornal espanhol El País na véspera da comemoração dos 50 anos da conquista da Copa do Mundo de 1970 (algo que lembra também a maneira de jogar do Barcelona dos anos 2000 e a da Seleção Holandesa de 1974): "P. ¿Qué
} 
Seria útil, porém, abrir aqui um parêntese reparador para dizer, reconhecendo e valorizando também a grande arte brasileira do drible (reconhecível num Pelé ou num Jairzinho, mas mais ainda num Garrincha) com seu elemento de improvisação, que o passe (em sua dimensão mais coletiva) e o drible (em sua dimensão mais individualista) na realidade não se opõem no modo da exclusão, mas se complementam perfeitamente (como bem o provam tanto esta seleção brasileira campeã de 1970 quanto a de 1958), demandando ainda um terceiro fundamento conclusivo que é o chute ou a cabeçada (visando o gol) precisos e fortes, e sem o qual os dois fundamentos anteriores seriam ainda insuficientes. ${ }^{16}$

E, a partir da observação anterior à do último parágrafo, eu gostaria também de sugerir uma hipótese de subversão ou transmutação da hierarquia tradicional dos valores futebolísticos (mas que todos reconhecerão já ter sido de algum modo incorporada há algum tempo por grandes e habilidosos times como a Seleção Holandesa de 1974 e o Barcelona do técnico Cruyff e depois o do Guardiola), propondo o passe e não o drible ou o chute como o elemento mais importante e decisivo do futebol e, juntamente com isso, elegendo não mais Pelé como o rei maior do futebol mundial, mas Didi, o meio de campo armador bicampeão mundial em 1958 e $1962 .{ }^{17}$

debe hacer un buen facilitador? $R$. Jugar a un toque. Dos como máximo. Cuando la pelota le llega ya la tiene que tener dominada y tiene que saber dónde están los compañeros. Rápidamente. El juego no se puede parar. Si controlas la pelota y la frenas, la jugada se detiene y la defensa te cierra los espacios. Esa era una de mis características. En el Cruzeiro yo jugaba mucho a un toque. Cuando llegué a la selección un día durante un partido vino Gérson y me dijo: 'Oye, juega con dos toques en vez de uno, ique así me dará tiempo de llegar!'. Yo le dije: 'Vale, con Pelé y Jairzinho jugaré a un toque, y contigo a dos'." (TOSTÃO. Tostão: "Fuimos revolucionários").

16 Ainda que eu possa reconhecer (também como um praticante de futebol na minha adolescência e juventude) que a verdadeira arte do drible (com o seu quê de imponderável ou inclassificável) é mais rara e difícil, tendo sido desde 1958 uma característica distintiva do futebol brasileiro, continuo a achar ingênua uma folclorização excessiva do drible "brasileiro", aproximando-o do samba ou da capoeira, pois ela desconhece precisamente a igual importância da arte do passe (e da do chute), igualmente característicos do bom futebol brasileiro, no que me parece ser uma típica deformação de um olhar estrangeiro que só consegue ver aqui o que lá está ausente (um Brasil turístico-cultural "do samba, das mulatas, do carnaval, da capoeira, da malandragem e do futebol"), tal como apresentado, por exemplo, no elogio ao drible feito por Olivier Guez no livrinho Éloge de l'esquive (GUEZ. Éloge de l'esquive).

17 Aliás, esta é uma lógica semelhante à que está na base da maior crítica que faz hoje o analista de futebol Tostão à maneira de jogar da Seleção Brasileira atual e dos últimos 30 anos, tal como ele o disse nesta já citada e recente entrevista ao jornal espanhol El País: "El fútbol es el pase. Uno de los principales problemas que tiene el fútbol brasileño es que desde hace 20 o 30 años valorizó poco el pase y sobrevaloró al jugador que dribla, remata y hace goles. Entonces, los grandes maestros de la pelota, los grandes jugadores, los grandes pensadores del mediocampo, como Gérson, Falcao, Cerezo, Rivelino, desaparecieron. El 
E também como o melhor jogador brasileiro (e também de todas as 16 seleções) da Copa de 1970 não o Gérson, que deu sim passes longos ou lançamentos sensacionais nessa Copa (como os dois do segundo e do terceiro gols do Brasil contra a Tchecoslováquia e o do terceiro gol do Brasil contra a Itália), mas não jogou em dois jogos importantes (sobretudo o contra a Inglaterra, mas também o contra a Romênia, em que Rivelino, um outro muito bom passador, também não jogou), e sim o Tostão, por seu passe pro Pelé (depois de driblar três zagueiros ingleses, dando de baixo das pernas do Bobby Moore) contra a Inglaterra, e por seus passes decisivos pro Clodoaldo e pro Jairzinho nos dois primeiros gols do Brasil contra o Uruguai, naqueles que foram, sem dúvida, os dois jogos mais difíceis do Brasil nessa Copa (ou também, o que ainda é mais difícil de compreender, por ter sabido criar espaços importantes no ataque, como na final contra a Itália, jogando sem bola e apenas por um posicionamento certo e oportuno no campo). Apenas como o segundo melhor jogador brasileiro eu colocaria, portanto, o craque e goleador do time, Jairzinho (com seus dribles e chutes rápidos e precisos), e, enfim, apenas como o terceiro melhor jogador brasileiro (que obviamente deu também muitos passes e dribles importantes e fez verdadeiros golaços) o "rei" Pelé.

Mas obviamente, sendo admitido o caráter coletivo desse jogo, e a importância, pra jogar bem e vencer, não só de um passe final decisivo (pra um finalizador que faz o gol), mas de toda a série de passes que pode resultar em gols (sendo sim importante que ao menos uma dessas séries de passes resulte em gol, assim como nesse caso que nenhuma das séries de passes do adversário possa resultar em gol, pra que se consiga a vitória), talvez fosse preciso dizer a evidência meio tola de que, em última instância, não faz sentido algum num jogo como esse querer escolher ou eleger o "melhor", pois ele não poderia ser o "melhor" sem os seus outros dez companheiros de time, sendo, por definição, o "melhor" apenas

mediocampo fue dividido entre volantes que defienden y volantes que juegan cerca del área rival, que driblan y llegan, como Pelé y Zico. Pero desaparecieron los grandes pensadores. Como Xavi, como Iniesta, como Kroos... Hasta hoy. La selección brasileña actual tiene a Casemiro, que es un gran jugador del medio hacia atrás, y a Neymar, que es un gran jugador del medio hacia el gol. Falta un gran pensador. Desde hace 30 años Brasil no tiene un jugador parecido a Xavi." (TOSTÃO. Tostão: "Fuimos revolucionários"). 
entre eles (ou eventualmente entre um grupo ainda maior de jogadores) e não sozinho, caso em que poderia ser apenas muitíssimo bom, no que linguística ou gramaticalmente é categorizado como a diferença entre o superlativo relativo e o superlativo absoluto. ${ }^{18}$

De algum modo, o próximo e maior lance de perigo do Uruguai no $2^{\circ}$ tempo, quando o jogo ainda estava 2 a 1 e poderia, portanto, ter sido empatado com já bem mais do que a metade do $2^{\mathrm{o}}$ tempo jogada (ainda uma vez alterando toda a possível sequência e resultado final da partida), poderia ser considerado também um claro exemplo desse caráter coletivo do jogo, pois o jogador brasileiro que se destaca aí, salvando o time, é precisamente o goleiro que (um pouco lento e inerte) parecia ter ou tinha mesmo falhado flagrantemente no gol do Uruguai, o nosso meio medíocre e vacilão Félix, que (semelhantemente ao que fizera num lance de perigo deste tipo no jogo contra a Inglaterra) dá uma ponte ágil e pega uma cabeçada firme e quase certeira, no ângulo alto esquerdo do gol, do atacante uruguaio (e quem poderia ser, pra completar com verossimilhança o seu perfil heroico no time adversário?) Cubilla, que com seu oportunismo (estava no lugar certo na hora certa) recebe sozinho e quase dentro da pequena área um cruzo muito bom do meio campo Rodriguez encobrindo toda a defesa brasileira e conclui quase fulminantemente (o locutor Valter Abrahão disse, então, interpretando o conjunto da atuação de Félix no jogo, que ele tinha se redimido da sua falha no gol do Uruguai...).

$\mathrm{Na}$ jogada do terceiro gol do Brasil, que, já no último minuto do tempo regulamentar do jogo ( $44 \mathrm{~m}$ do $2^{\circ}$ tempo), define irreversivelmente a vitória da seleção brasileira, chama a atenção primeiramente o modo como, depois que Carlos Alberto corta uma bola no lado direito da defesa dando um chute alto em direção ao meio do campo (ou seja: uma isolada consciente e não pra ir pra lateral,

\footnotetext{
${ }^{18} \mathrm{Na}$ já citada entrevista ao jornal El País, Tostão relaciona também a perda deste sentido coletivo elementar no atual futebol, sentido presente sobretudo no passe, com uma sociedade gananciosa em que o individualismo é o valor supremo: "El pase es un símbolo del juego colectivo y de la vida en común, de la solidaridad, del respeto mutuo. Las personas tienen todo el derecho a querer mejorar su vida, a disfrutar de placeres y ganar dinero. Pero sin olvidar que los demás también quieren lo mismo. En Brasil creció una sociedad egoísta: una sociedad para la explotación de otra sociedad. El sentido de la comunidad disminuyó en la sociedad y en el campo disminuyó el juego colectivo. Brasil juega un fútbol brillante en lances individuales. Juega a meter goles. Nadie juega para el compañero, nadie busca una respuesta, nadie piensa en la organización. No es la lógica del juego, es la lógica de la ganancia." (TOSTÃO. Tostão: "Fuimos revolucionários").
} 
mas pra poder ainda ser aproveitada), Pelé chega junto e disputa a bola pelo alto com o zagueiro uruguaio Ubiña, forçando que ele corte com mais força e dando um rebote pro Tostão, que então toca rápido e preciso pro Pelé que, por sua vez, avança rápido com a bola pela esquerda, enquanto Tostão vai pra dentro da grande área adversária, puxando a atenção de dois beques uruguaios (como já sabemos, jogando sem bola e apenas pelo posicionamento, algo que Tostão faria muito bem também na final contra a Itália) e Pelé, ficando sozinho ao dar uma parada rápida (que quase parece um corte), mas bem marcado de frente pelo mesmo zagueiro uruguaio (Ubiña) que cortou o "balão" de Carlos Alberto, em vez de partir pra tentar o drible dentro da área (algo mais característico de um Jairzinho nessa Copa), pra definir logo tudo sozinho, percebe bem a chegada do Rivelino logo atrás e um pouco do lado (que ele sabe bem que tem um chute potente e estaria melhor colocado do que ele) e simplesmente rola bem macio ao seu lado direito pra que Rivelino tomando impulso possa chegar batendo forte e antes que qualquer beque possa cortar a bola, e que é justamente o que ele faz, com um chute fortíssimo rasteiro (uma "porrada") bem preciso e rápido no lado direito do gol (numa ligeira diagonal que lembra a do primeiro gol contra o Peru, mas sem a curva e um pouco mais no meio do gol), não permitindo que Mazurkiewicz reagisse em tempo de tocar na bola e impedir que ela entrasse, ainda uma vez um golaço.

0 curioso é que, revendo agora os jogos, eu voltei a reparar, como quando criança, na maneira meio "irritada" e "doida" (como se um "bicho estranho" tivesse tomado conta dele, ou o contrário, como se ele estivesse enfim ficando livre de um "demônio qualquer") como o Rivelino comemorava os gols, socando o ar pra baixo com as duas mãos e balançando a cabeça (e andando num passo meio duro e militar): um pouco menos no gol de falta contra a Tchecoslováquia (empatando o jogo numa hora difícil pro Brasil), já bem pronunciadamente no $1^{\text {o }}$ gol do jogo contra o Peru, e enfim meio tresloucadamente nesse terceiro gol contra o Uruguai, que assegurava de vez a presença do Brasil na final dessa Copa. Agora, no entanto, como passei também a ficar às vezes muito nervoso e chato antes de aulas mais importantes ou participações em eventos, e depois, tudo dando certo (nem sempre, mas o mais das vezes), a me sentir aliviado e feliz e até mesmo justificado, como se aquilo tudo fosse um mero ciclo meio dramático e sem grande importância diante 
de uma boa performance, que era afinal o que realmente interessava, eu (como um bom e ridículo Zelig) me identifiquei um pouco com o Rivelino e pareci pela primeira vez ter entendido aquele tipo de reação (que confirmava, aliás, a impressão de "irritado" que ele dava às vezes ao longo do jogo, mas sempre jogando bem...... ${ }^{19}$

Mas, apesar de decidido, o jogo não estava acabado e reservava aquela que seria talvez a sua maior surpresa, pelo insólito do drible e a beleza de conjunto de uma jogada bem perigosa ainda que não resultando em gol, e também um lance pra demonstrar de vez a craqueza soberana do (agora justificadamente) "rei" Pelé. 0 que farei aqui é apenas descrever de um modo simples e mais ou menos direto a jogada (a partir do que revi durante o VT, mas também em repetidas consultas aos diferentes compactos do jogo no YouTube), pra acabar de compor o meu relatoensaio do conjunto dessa partida e sem querer focá-la excessivamente, já que sabendo que ela foi, em seus breves nove segundos, detalhada e exaustivamente descrita e comentada nas seis páginas iniciais (ou ao menos quatro voltadas exclusivamente para o futebol) do excelente romance $O$ drible (em homenagem precisamente a esse drible de Pelé em Mazurkiewicz) de Sérgio Rodrigues, no que será uma operação minha de maliciosa e intertextual simplificação narrativa, que poderia definir ironicamente como a de dar um drible no drible d'O drible de Sérgio Rodrigues. ${ }^{20}$

A jogada começa com Jairzinho, que recebe a bola pela esquerda (apenas mais um exemplo da mobilidade e possível troca de posição dos três atacantes brasileiros) e toca macio pra Tostão então encostando do seu lado direito, mais ou menos no meio de campo, o qual de imediato avança com a bola obviamente sem precisar olhar pra ela (enquanto Jairzinho segue pela esquerda puxando com isso o lateral direito uruguaio), e percebe então que Pelé já está passando em passadas largas, "sorrateira e fulminantemente" (se a conjunção um pouco contraditória

\footnotetext{
19 Para esse clique interpretativo iluminador foi importante também a leitura do seguinte testemunho de Tostão (que fiz com o prazer de um sorriso leve e silencioso): "O Rivelino era ranzinza. [...] Ele não parava de reclamar. Era o maior chorão do mundo. [...] Chorão. O dia inteiro reclamando, sempre tem uma coisa ruim. Sabe que tem pessoa assim, né? Cri-cri. [...] Não é que ele levava aquilo a sério, não. Não que aquilo trazia prejuízo pra ele. Era o hábito de reclamar, de achar que tudo tá ruim. No jogo, por exemplo, quando ele jogava, qualquer bola que não desse certo ele ficava resmungando." (TOSTÃO. Na folga podia ir a festinhas, tomar uma cervejinha ou ir pra igreja rezar).

${ }^{20} \mathrm{Cf}$. RODRIGUES. O drible, p. 1-6.
} 
desses dois advérbios for possível), um pouco acima à sua direita, ${ }^{21}$ e Tostão então dá um passe preciso (e sem força em demasia) na diagonal um pouco à frente de Pelé que já chega correndo na meia lua sem nenhum beque o acompanhando, ${ }^{22}$ enquanto o goleiro Mazurkiewicz sai rápido e meio desesperado pra tentar interceptar a bola (ultrapassando a linha da grande área), com os dois braços meio abertos, como se querendo pegar ao menos o atacante, ${ }^{23}$ que poderia ter chegado dando um corte pra esquerda (pra depois ficar livre pra marcar, se ele o goleiro não conseguisse fechá-lo na bola ou sem ela pra fazer uma falta), ${ }^{24}$ mas que passa correndo pela esquerda, sem tocar na bola e a deixando enganadoramente passar, enquanto ele o goleiro fica sem ver a bola que continua pela direita nem o atacante que passa pela esquerda, numa bela e inusitada coreografia dinâmica em cruz, com Pelé, logo depois de ter passado pelo goleiro, voltando num laço pra pegar a bola do outro lado, ${ }^{25}$ mas meio de costas pra ela e se virando de novo pra tentar um chute rasteiro não diretamente pro canto direito ou pro meio do gol, pois um zagueiro (também correndo desesperado) já fechava ali o ângulo, mas no canto oposto, sem que ele o zagueiro (Ancheta), pego no contrapé e já meio caindo

\footnotetext{
${ }^{21}$ Murilo, o antigo jornalista esportivo, então já com uns 80 anos de idade, e narrador dessa jogada (mas sempre pra seu filho Neto) no romance de Sérgio Rodrigues, diz assim: "Tostão conduz a bola, e [...] Pelé aponta no canto superior direito do quadro e [...] então [...] nós vemos aquilo que o Tostão também acaba de ver, Pelé se projetando da meia-direita feito um bicho, uma pantera com sangue de guepardo." (RODRIGUES. O drible, p. 9).

${ }^{22}$ Ainda segundo Murilo, o narrador dessa jogada no romance de Sérgio Rodrigues: "O passe do cara é perfeito [...]. Um miligrama de força a mais ou a menos, seria quase perfeito, praticamente perfeito, mas não, é perfeito, metido da meia-esquerda com o pé esquerdo numa linha diagonal de desenhista de Brasília, a mais leve curvatura, em direção ao centro da grande área." (RODRIGUES. O drible, p. 10).

${ }^{23}$ Ainda segundo o narrador Murilo (no romance $O$ drible): "O quíper uruguaio faz o que pode, entra no semicírculo um milésimo de segundo antes do Pelé, mas não a tempo de interceptar a bola. Ela fica entre os dois e nós voltamos a sentir, como o Mazurka também sente, que está mais para o negão que vem no embalo. O que o bom goleiro da Celeste faz é se ajoelhar e, mesmo já estando fora da área, que remédio, abrir os braços." (RODRIGUES. O drible, p. 10).

${ }^{24} \mathrm{Na}$ versão da quase íntegra desta sequência da jogada pelo narrador Murilo (em $O$ drible): "O Mazurkiewicz [...] só pode rezar para que o brasileiro não faça o que um jogador da envergadura dele provavelmente vai preferir fazer, isto é, cortar o goleiro para a esquerda, coisa fácil na passada em que vem, movimento que levaria a das duas, uma: ou o goleiro agarrar faltosamente as pernas do Pelé ou o Pelé concluir de canhota para o gol aberto ou quase, defendido só pelo zagueiro que, não demora, vai entrar no quadro esbaforido feito quem está prestes a perder o último trem e acabar às cambalhotas pelo chão." (RODRIGUES. O drible, p. 11).

${ }^{25}$ Segundo o narrador Murilo (no romance $O$ drible): "O que o Pelé tem que fazer agora é [...] frear para corrigir radicalmente seu ângulo de deslocamento, frear e no mesmo instante recomeçar a correr na outra direção, atrás da bola agora, ele que vinha no tropel mais desembestado fingindo ignorá-la. O cara tem que dar uma quebrada de noventa graus e não perder velocidade porque [...] há que chegar na bola antes dos adversários e ainda com um bom ângulo de chute." (RODRIGUES. O drible, p. 12).
} 
desengonçado, consiga tocar na bola que passa, no entanto, bem rente à trave esquerda e sai pra fora, ${ }^{26}$ enquanto Pelé, desta vez mais indiferente (pois a partida já estava ganha), sai mordendo tranquilo uma pedrinha de gelo, como se não estivesse nem aí pro lance feérico que (como um bom jogador de peladas, pouco preocupado com o "rendimento efetivo" das suas brincadeiras) ele tinha acabado de protagonizar.

Quando, no romance $O$ drible, o narrador Murilo, falando com o filho Neto, se pergunta por que Pelé não tentou cortar Mazurkiewicz pela esquerda (a jogada então mais óbvia e com maiores chances de gol ou, ao menos, de uma falta perigosa com a provável expulsão do goleiro), ele mesmo responde pra si: “[Pelé] está farto de saber que é um mito, um semideus, o que tem a perder tentando ser um deus completo? Aí ele não faz o certo, faz o sublime". ${ }^{27}$ Pra um pouco depois concluir de um modo talvez demasiado teológico-judaico e eloquente (o personagem narrador e não necessariamente o autor Sérgio Rodrigues): "Pelé desafiou Deus e perdeu. Imagine se não perdesse. Se não perdesse, nunca mais que a humanidade dormia tranquila. Pelé desafiou Deus e perdeu, mas que desafio soberbo. Esse gol que ele não fez não é só o maior momento da história do Pelé, é também o maior momento da história do futebol".28

Seguindo uma trilha mais lúdica (ou ludopédica), indicada levemente no finzinho do penúltimo parágrafo, quero sugerir uma alternativa não judaico-cristã pra interpretar a soberana e, a seu modo, brincalhona escolha de Pelé pela jogada mais bela e difícil (essa insólita "gaúcha" apenas de corpo), ao se defrontar na meia lua do campo adversário com o goleiro uruguaio Mazurkiewicz (considerado depois o melhor goleiro dessa Copa), desperdiçando uma grande chance de gol. Se considerarmos o contexto desta jogada, depois de um passe de costas (e de "pura classe") pro Tostão lançar precisamente pro Jairzinho no $2^{\mathrm{o}}$ gol, e pouco depois

${ }^{26}$ Ainda segundo o narrador Murilo (no romance $O$ drible): "Pelé consegue fazer as duas coisas [...]: vai chutar e fazer o gol. Acontece que não é tão simples, porque Pelé agora está do lado errado da bola, meio de ombro para o gol, tem que bater nela num movimento de meio giro. E aí [...] ele erra. Pelé erra: [...] enquanto o tal Ancheta que ia perder o trem se estabaca na grama, a bola chutada por Pelé tira fino da trave direita do Uruguai." (RODRIGUES. O drible, p. 13).

${ }^{27}$ RODRIGUES. O drible, p. 11.

${ }^{28}$ RODRIGUES. O drible, p. 13. Um outro uso (ou interpretação) experimental do futebol pra pensar uma questão essencialmente filosófica está no breve ensaio La Mélancolie de Zidane do romancista belga (radicado em Paris) Jean-Philippe Toussaint (TOUSSAINT. La Mélancolie de Zidane), comentando a cabeçada de Zidane na barriga do zagueiro italiano Materazzi, na prorrogação da final da França contra a Itália na Copa de 2006 na Alemanha, que provocou a sua expulsão, desfalcando o time francês numa hora decisiva, e acabou dando fatidicamente a vitória e o título de campeão ao time italiano. 
também de Pelé ter rolado bem macio pro Rivelino fuzilar rasteiro e fazer o $3^{\circ} \mathrm{gol}$, assegurando a vitória do Brasil, a impressão que se tem é a de uma liberdade ou a de um excesso paradoxal de habilidade que não precisa mais se submeter servilmente à necessidade de fazer gols pra ganhar o jogo, podendo, enfim, brincar apenas por brincar, como uma criança ou um deus grego antigo gargalhando (como os de Homero, se banqueteando ou fazendo alguma pilhéria obscena). ${ }^{29}$

Se juntamente com Roman Dilcher, no capítulo VII, "The Divine Game", de Studies in Heraclitus interpretarmos o termo grego aión não como "tempo de vida" ou "eternidade",30 mas (a partir da sugestão de Émile Benveniste de um sentido original não temporal) como "força de vida" ou "vitalidade" ["[...] não 'tempo de vida', mas 'força de vida, fonte de vitalidade'”],31 seria possível encontrar no enigmático fragmento $52 \mathrm{D}$ ou $93 \mathrm{M}$ de Heráclito de Éfeso (que traduzirei experimentalmente aqui logo abaixo) $)^{32}$ algo que talvez figurasse bem o excesso de vitalidade brincalhona do "rei" Pelé ao fazer aquela jogada (ou dar aquele insólito e desconcertante drible):

aiòn paîs esti, paísdon pesseúon: paidòs he basileía.

"vitalidade é uma criança, que brinca jogando dados: da criança a realeza".

Mas se consideramos também a dificuldade de uma apreensão mais precisa do termo pesseúonn, um particípio presente que traduzi por "jogando dados" (sendo do mesmo radical do aoristo 2 épeson do verbo pípto "cair"), mas que poderia remeter a um jogo de tabuleiro com suas peças, jogado com golpes de dados ou sorteios (como uma espécie de "gamão" ou petteía), e que exigiria não apenas sorte, mas também

\footnotetext{
29 As cenas mais emblemáticas do famoso "riso inextinguível" (ásbestos gélos) dos deuses homéricos são o banquete no fim do canto 1 da llíada (584-604), em que os deuses riem do deus Hefesto, uma espécie de garçom manco, depois de uma briga conjugal entre Zeus e Hera, e a conversa entre Posêidon, Hermes e Apolo na história da segunda canção de Demódoco no canto 8 da Odisseia (322-343), quando eles presenciam Ares e Afrodite em adultério, presos na cama por uma rede fina tecida por Hefesto, o marido enganado. Um estudo mais antigo (e que se tornou referência) sobre esses deuses homéricos ridentes é o de Paul Friedländer, "Lachende Götter" (FRIEDLÄNDER. Lachende Götter).

${ }^{30}$ DILCHER. Studies in Heraclitus, p. 145-157.

31 "[...] non 'temps de vie', mais 'force de vie, source de vitalité'” (BENVENISTE. Expression indo-européenne de l'éternité, p. 107).

${ }^{32}$ Apesar de estar adotando aqui a pontuação da edição de Diels-Kranz, a edição textual que está me servindo de referência, com seu aparato crítico mais preciso e seu posterior comentário, é a de Miroslav Marcovich: Heraclitus: Greek text with a short commentary, onde o texto grego do fragmento 93 é apresentado com suas variantes e fontes antigas nas páginas 490-492, e depois traduzido e comentado nas páginas 493-495 (MARCOVITCH. Heraclitus: Greek text with a short commentary, p. 490-495).
} 
alguma habilidade, talvez chegássemos a uma imagem ainda mais próxima do que Pelé como um maximamente exímio jogador fez naquela jogada, pois segundo Roman Dilcher (comentando Heráclito 52 D): “O jogo da criança parece implicar uma coincidência de sorte e habilidade numa atividade planejada e regulamentada, apesar de sem finalidade, isso é: essencialmente lúdica (brincalhona)".33

Não sem razão, Dilcher irá também lembrar - a partir de um modelo de polaridade que atravessa o pensamento grego arcaico, mas que em Heráclito ganha uma dimensão de inteligibilidade acrescida pela proposição conjunta da complementaridade dos opostos, ou seja: a partir de um modelo em que, para retomar o exemplo deste fragmento $52 \mathrm{D}$, a liberdade ou despreocupação da criança (ou do deus) que brinca só é inteligível por sua oposição ao necessário sofrimento de um mortal (adulto) sujeito a um tempo irreversível e que em cada ação decide muito seriamente e de uma vez por todas a sua vida ${ }^{34}$ (ao menos naquele momento e no que dele resulta) - o quanto a figura do deus Apolo destruindo com facilidade a muralha dos aqueus na Ilíada é, em sua indiferença à dimensão da utilidade ou do ganho, comparada com pertinência à de uma criança erigindo e destruindo "muralhas" de areia na praia, apenas para brincar: ${ }^{35}$

\section{[...] [Apolo] com a égide valiosa: derrubou a muralha dos aqueus bem fácil, como menino faz com areia na praia, aquele que, após construir um brinquedo em sua meninice, aniquila tudo de novo, brincando, com os pés e as mãos." \\ (Ilíada XV, 361-364, tradução de Christian Werner). ${ }^{36}$}

Enfim, depois dessa última e sensacional jogada de Pelé, o jogo estava praticamente acabado, mas curiosamente o VT e os compactos registram uns 15 ou

\footnotetext{
33 DILCHER. Studies in Heraclitus, p. 154 (tradução minha). Como lembra também pertinentemente R. Dilcher, a imagem do "jogo de dados" (petteía ou kybeía) era, no mundo grego contemporâneo de Heráclito (o do século $V$ a. C.), usada com frequência como uma metáfora para as vicissitudes da vida. No caso do resultado imprevisível de uma batalha, por exemplo, Ésquilo (Sete contra Tebas, 414) dirá que "Ares decide a obra com os dados (en kýbois)." (DILCHER. Studies in Heraclitus, p. 154, tradução minha).

${ }^{34}$ Segundo R. Dilcher: "A metáfora do jogo divino expressa assim sucintamente o básico duplo aspecto da religião grega. De um lado estão os deuses imortais gozando uma olímpica bemaventurança, e do outro estão os homens expostos ao sofrimento, ao destino e à morte. Um deus, mesmo quando está engajado nos negócios humanos, não pode ser seriamente afetado em sua vida fácil pelas consequências de seus atos. O que é letal para o homem não é mais do que uma aventura lúdica e uma distração para um imortal." (DILCHER. Studies in Heraclitus, p. 156, tradução minha).

${ }^{35} \mathrm{Cf}$. DILCHER. Studies in Heraclitus, p. 155-156.

${ }^{36}$ HOMERO. Ilíada, p. 435.
} 
20 últimos segundos antes do apito final do juiz, em que o Brasil simplesmente toca a bola na defesa, como se já não querendo nada ou (o que é um pouco diferente) querendo perigosamente começar a colocar os uruguaios na roda, numa sequência que começa a se assemelhar à de um tradicional e humilhante "olé", que quase nenhum adversário suporta por muito tempo sem, com alguma razão, querer interrompê-lo até mesmo com violência, se for preciso. E o que parece premonitório, apesar de aparentemente insignificante, é que os dois últimos lances, um passe e depois uma tentativa de drible meio brincalhona também (o jogo terminando justamente com um corte mais brusco de um uruguaio já impaciente) são de Clodoaldo, que na final contra a Itália iria querer "enfeitar" com um drible temerário um corte de um ataque italiano (segundo ele mesmo querendo se justificar depois, porque por sua posição ele não teria tido uma outra alternativa) e acabaria perdendo perigosa e fatalmente a bola pro atacante italiano Boninsegna que marcaria o gol de empate contra o Brasil mais pro fim do $1^{0}$ tempo, 37 alterando radicalmente a configuração da partida (assim como depois, no começo do $4^{\mathrm{o}}$ gol do Brasil, num mesmo tipo de jogada, mas que dá certo, Clodoaldo irá driblar uns três ou quatro jogadores italianos, ${ }^{38}$ antes de passar a bola pro Rivelino no lado esquerdo ainda no campo do Brasil, e o Rivelino, por sua vez, dá um passe mais longo pro Jairzinho na esquerda, que avança então em direção à área adversária e toca pro Pelé, que, bem cercado por mais de um italiano, toca bem maciamente pro lado direito onde Carlos Alberto está chegando

\footnotetext{
${ }^{37}$ As denegações de Clodoaldo parecem sinalizar bem o quanto um erro pode ser traumático e inapagável em uma torturante memória (ainda que, diferentemente do que ocorreu com o goleiro Barbosa na final da Copa de 50, aqui o contexto maior é consagrador e de vitória): "Eu tive um erro contra a Itália. [...] Então, na hora em que eu recebi a bola, ela quicou no meu pé. Eu tava saindo da defesa para o ataque, eu não esperava e ela veio. Aí, ele [Boninsegna] percebeu e correu de lado. Como eu percebi que ela ia passar e ele ia dominar e sair pra fazer o gol, tentei o único recurso que eu tinha. Não é que eu quis enfeitar a jogada, eu tive só aquela oportunidade, de tentar jogar a bola lá na esquerda. Mas quando eu fiz assim [0 movimento] pra dar pro Everaldo, e ela quicou porque estava molhada, ele [Boninsegna] já estava do lado. Se ele estivesse na minha frente, talvez até desse pra tentar dominar. [...] Eu assumo a responsabilidade. Quando a gente erra, tem que assumir. De qualquer forma, não me abalou. Mas tá bom, já passou, graças a Deus." (CLODOALDO. Eu deixei a Itália quase que nocauteada para que nós pudéssemos fazer o gol).

38 " $E$, depois, a jogada: eu driblei uns quatro italianos no meio de campo. [...] Eu até brinquei em alguns momentos, e brinco até hoje, que ali eu deixei a Itália quase que nocauteada para que nós pudéssemos fazer o gol que saiu." (CLODOALDO. Eu deixei a Itália quase que nocauteada para que nós pudéssemos fazer o gol).
} 
correndo mais velozmente e pega bem firme na bola mandando no cantinho esquerdo do gol, sem dar nenhuma chance ao goleiro).

Mas este comentário sobre esses anódinos segundos finais desse jogo, em que o Brasil simplesmente tocou a bola na defesa e nada de importante aconteceu, e que tentei valorizar aqui com uma observação sobre uma tendência pro drible meio sintomática (e talvez premonitória) por parte do Clodoaldo, permitiria também um comentário final concomitante sobre a edição dos compactos de jogos, em que geralmente os instantes de menor perigo de gol ou menos sensacionais (em termos de habilidade, erro ou algum elemento insólito) geralmente são omitidos, e sobre o próprio funcionamento da memória ordinária que analogamente tenderia a apagar a grande maioria dos instantes insossos ou meio amorfos (quanto a eventos significativos) e que, no entanto, compõem um volume ou faixa considerável do que costuma se passar numa partida e apenas em contraste com a qual os chamados "eventos significativos" podem se destacar. ${ }^{39}$

E digo isso também porque - talvez já parcialmente atingido por um déficit de memória recente, que pode não ser necessariamente (assim o espero) uma espécie de pré-Alzheimer (podendo também ser causado meramente pelo acúmulo excessivo de informações novas que atualmente circulam na internet e nas redes sociais) - nesta experiência recente de ter revisto o jogo inteiro dessa semifinal da Copa de 70, assim como ocorre com frequência também com jogos ao vivo de futebol ou vôlei (mesmo os dos torneios mais importantes) ou filmes ou séries (mesmo os/as melhores), me parecia que eu estava esquecendo, já no dia seguinte ou na semana posterior, quase tudo se não os gols, as bolas na trave ou os lances de muito perigo, o que fazia, portanto, da minha memória de grandes jogos da seleção brasileira, mesmo em Copas bem mais recentes, alguma coisa bem próxima, quando ela ainda conseguia salvar alguma coisa, dos compactos mais enxutos e curtos desses jogos (aos quais, por sinal, três ou quatro dias depois de

\footnotetext{
${ }^{39}$ Mas, assim como com o sofrimento físico ou psíquico mais agudo, não seria também o esquecimento dessa massa majoritária de "instantes insossos e amorfos" que compõem as partidas de futebol exatamente o mais desejável e salutar? Ou deveríamos supor a consciência e o registro (ou memória), não importando do que exatamente, como um valor em si? Por outro lado, porém, como é que eu iria me lembrar, uma vez só que fosse, dos nomes de certos jogadores do time uruguaio (ou tcheco, ou inglês, ou italiano) ou de antigos locutores e comentaristas dos anos 70, se não fosse a minha frequentação dos VTs desses jogos na TV, ou dos compactos deles no YouTube?
} 
ter visto o jogo, eu tive vergonhosamente de recorrer, via YouTube, pra poder descrever com mais precisão, neste presente e enfim inesperado ensaio, até mesmo os gols e as jogadas mais perigosas e importantes). ${ }^{40}$

Por um lado, seria mesmo muito difícil imaginar compactos de jogos editados segundo critérios não convencionais, excluindo, por exemplo, precisamente os gols e os lances de maior perigo ou beleza, ${ }^{41}$ e - não fazendo jus ao nome e à ideia de "compacto" - se estendendo muito com a inclusão de muitas jogadas insignificantes ou mesmo de paralisações do jogo. Assim como seria também pouco imaginável que, na perturbadora e bizarra ausência de jogos de futebol ao vivo nesta quarentena pandêmica estendida, os jogos ruins de campeonatos regionais da segunda ou terceira divisão começassem a ser transmitidos na íntegra. Mas, por outro lado, o efeito, como com os 50 anos da conquista da Copa de 70, de uma repetição incansável, em mais de um canal de esporte, de alguns gols ou lances memoráveis da seleção brasileira era (sobretudo levando-se em conta um já prévio saber de todos os seus resultados e mesmo dos seus gols mais importantes) um bocejante tédio e um complementar desejo de alguma surpresa ou de uma ignorância fundamental e constitutiva quanto ao que ainda está por acontecer. 0 que um VT de um jogo inteiro permitia era, ao menos, reconstituir o contexto em que cada jogada perigosa ou gol tinha acontecido, de modo a tornar possível perceber melhor o como (ou quanto) outras possibilidades

40 No entanto, imaginar inversamente uma memória maximamente precisa (como a do personagem "Funes, o memorioso", do conto homônimo de Jorge Luis Borges [cf. BORGES, Fiç̧ões, p. 539-546], capaz de se lembrar de um dia inteiro vivido há anos) e que permitisse durante anos guardar todos os eventos e micro-eventos que compõem a uma hora e meia e mais alguns acréscimos de uma partida de futebol seria também ligeiramente monstruoso e implicaria uma disponibilidade de atenção que ordinariamente não pode ser subtraída com facilidade da vigília presente com seu séquito de demandas pra tarefas práticas mais ou menos urgentes apenas pra mera manutenção da vida.

${ }^{41}$ A hipótese inversa também era bastante estranha (ainda que pudesse ocorrer na memória ordinária, sobretudo a de jogos terminados em 1 a 0): a de uma compactação máxima com a necessária escolha de apenas um grande lance (gol ou não) de cada partida, caso em que curiosamente, numa partida como esses 3 a 1 pro Brasil contra o Uruguai (e em que pese a atenção dada ao lance pelo romance $O$ drible de Sérgio Rodrigues), não seria o drible de corpo de Pelé em Mazurkiewicz a jogada escolhida, mas, pelo sufoco que então passava o Brasil e pelo inusitado da chegada à frente e o chute certeiro de bate-pronto do médio-volante Clodoaldo, o primeiro gol do Brasil empatando a partida no último minuto do $1^{\circ}$ tempo, que poderia (assim como o $2^{\circ}$ de Jairzinho, semelhantemente com um passe de Tostão) ser interpretado como resultando também - em sua conjunção misteriosa de habilidade, raça e sorte - da intervenção benfazeja decisiva de uma divindade (tal como sugerido no trecho de meu ensaio citado na nota 13). 
estavam também presentes ali e o relativo mistério de apenas uma delas (e da exata maneira como aconteceu) ter sido a que teve lugar de fato.

\section{[NOTA FINAL SOBRE O CARÁTER BIOGRÁFICO E AUTOBIOGRÁFICO DESTE RELATO-ENSAIO]}

Nesta nota final mais estendida (por isso transferida para o corpo mesmo do texto) e escrita uns três meses após a conclusão deste meu relato-ensaio, eu gostaria apenas de fazer uma breve reflexão teórica sobre o caráter biográfico inevitável (para os jogadores da Seleção Brasileira e, mais particularmente, para o Tostão) dos vídeo-tapes dos jogos do Brasil na Copa do Mundo de futebol de 1970, assim como sobre o seu caráter também autobiográfico para mim que havia assistido quando criança a todos esses jogos na televisão, tratando-se nos dois casos de um material básico documental que constitui uma prova fotográfico-fílmica irrefutavelmente objetiva da existência deste passado, hoje já um pouco distante, exatamente como ali registrado.

0 meu ponto de partida para essa de algum modo óbvia reflexão teórica será o do caráter fílmico ou cinematográfico destes vídeo-tapes, por sua vez baseado em seu caráter inevitavelmente fotográfico, ou seja: o de fotogramas (minimissimamente diferenciados) numa contínua e muito longa justaposição, transmitindo, quando passados em uma rápida sucessão, o efeito do "movimento" (em grego antigo, para retomar a etimologia, kínema ou "cinema"), tal como o da porção da vida mesma que foi filmada. Mas também - e isso é o mais importante o de fotogramas que registram, sem nenhuma deformação ou transmutação deliberada (ainda que pressuponham as escolhas de ponto de vista, enquadramento, luz, cor e foco do fotógrafo ou operador de câmera), o evento mesmo que foi em cada caso aquela partida de futebol de uma hora e meia regulamentar de duração. ${ }^{42}$

42 O meu ponto de partida para a consideração desta base fotográfica, eminentemente referenciada à realidade, do filme ou cinema é a obra teórica (e uma suma de todo o seu trabalho investigativo sobre o cinema) de Siegfried Kracauer, Theory of Film, cujo primeiro e longo capítulo preparatório é justamente sobre a fotografia, "1. Photography" (cf. KRACAUER. Theory of Film: The Redemption of Physical Reality, p. 3-22), que Ihe dá então os elementos para estabelecer as propriedades básicas (idênticas às da fotografia) e técnicas (diferentes das da fotografia, porque tendo como núcleo a edição ou montagem) do meio fílmico no subcapítulo "Properties of the medium" do capítulo 2 "Basic concepts" deste mesmo livro (cf. KRACAUER. Theory of Film, p. 28-30). 
Será, portanto, a partir da natureza basicamente fotográfica dos vídeo-tapes destas seis partidas da campanha vitoriosa da Seleção Brasileira de futebol na Copa do Mundo de 1970 e neles da forte e hegemônica referência à realidade mesma de cada longo evento (ou partida de futebol) representado visualmente em duas dimensões (e com a também possível captação do som ambiente no estádio e campo de futebol em que cada partida ocorreu), que eu proporei aqui, aplicado ao registro cinematográfico (isto é: dos fotogramas em sucessão), a definição do que constituiria, segundo Roland Barthes em A câmara clara, a essência ou o "noema" fático da fotografia: Isso-foi, ${ }^{43}$ pois, diferentemente da pintura ou do discurso em seus modos de representação abertos à simulação ou imaginação,44 "na Fotografia jamais posso negar que a coisa esteve lá. Há dupla posição conjunta: de realidade e de passado". 45

Mas, além da inegável e comprovada realidade (então viva) do passado registrado em imagem, a fotografia também carrega em si (como potencialidade certeira e inevitável) o futuro necessário de todo indivíduo humano: a sua morte e desaparição enquanto indivíduo. Mais do que um detalhe quase inapreensível que dá sabor e graça singulares à imagem fotográfica de um indivíduo, segundo Barthes o seu punctum, em oposição a todas as informações objetivas sobre sua época e seu meio social (o que Barthes chama de studium), o punctum ontológico da fotografia estaria justamente na morte. Falando da foto (por Alexander Gardner) de um jovem (Lewis Payne) preso, porque tentou assassinar um secretário de Estado norte-americano, aguardando o seu enforcamento numa cela, Barthes diz: "A foto é bela, o jovem também: trata-se do studium. Mas o punctum é: ele vai morrer. Leio ao mesmo tempo: isso será e isso foi; observo com horror um

\footnotetext{
${ }^{43}$ BARTHES. A câmara clara: nota sobre a fotografia, p. 115.

44 'Chamo de 'referente fotográfico' não a coisa facultativamente real a que remete uma imagem ou um signo, mas a coisa necessariamente real que foi colocada diante da objetiva, sem a qual não haveria Fotografia. A pintura pode simular a realidade sem tê-la visto. $O$ discurso combina signos que certamente têm referentes, mas esses referentes podem ser e na maior parte das vezes são 'quimeras'." (BARTHES. A câmara clara, p. 114-115).

45 BARTHES. A câmara clara, p. 115. Essa prioridade da existência real do referente humano (então vivo) na fotografia é também proposta por Walter Benjamin no seu célebre ensaio "Pequena história da fotografia": "[...] na fotografia surge algo estranho e novo: na vendedora de peixes de New Haven, olhando o chão com um recato tão displicente e sedutor, preserva-se algo que não se reduz ao gênio artístico do fotógrafo Hill, algo que não pode ser silenciado, que reclama com insistência o nome daquela que viveu ali, que também na foto é real, e que não quer extinguir-se na 'arte'." (BENJAMIN. Pequena história da fotografia, p. 93, itálicos meus).
} 
futuro anterior cuja aposta é a morte". ${ }^{46}$ Mas se este exemplo extremo facilita a compreensão desta dimensão ou elemento da fotografia, qualquer foto ordinária de uma pessoa (não necessariamente condenada à morte pela justiça) com um possível futuro mais largo também conteria esta dimensão: "Diante da foto de minha mãe criança, eu me digo: ela vai morrer; estremeço, tal como o psicótico de Winnicott, por uma catástrofe que já ocorreu. Que o sujeito já esteja morto ou não, qualquer fotografia é essa catástrofe". ${ }^{47}$

Mas talvez pudéssemos acrescentar que a esta dimensão moritura potencial contida em qualquer imagem fotográfica de um indivíduo humano mortal se superporia também a do seu inevitável envelhecimento, não apenas genericamente como temporalidade que admitiria também uma dimensão positiva de florescimento na passagem da infância à juventude e desta à maturidade, mas sim como passagem da maturidade à velhice com todas as esperáveis consequências físicas negativas (aumento da probabilidade de doenças mais ou menos graves, e perda progressiva de vitalidade, agilidade e beleza) que esta última pressupõe, sendo o envelhecimento (neste sentido mais estrito) mais decisivo e dramático para os atletas como os jogadores de futebol, cuja maturidade máxima dificilmente ultrapassa ou ultrapassava os trinta ou trinta e cinco anos de idade (por exemplo, no time titular da Seleção Brasileira da Copa do Mundo de 1970, os mais velhos eram Félix, com 32 anos, Brito, com 30, e Gérson e Pelé, com 29, todos eles sabidamente jogando já sua última Copa do Mundo).

Assim, portanto, ainda que não sejam tantos os jogadores titulares (ou que, ao menos, jogaram alguma partida) desta Seleção Brasileira hoje já mortos mesmo que diferenciadamente - Everaldo morreu em 1974 num acidente de automóvel, com 30 anos de idade; Fontana morreu em 1980 de infarto, com 39 anos de idade; Félix morreu em 2012 de enfisema pulmonar, com 74 anos de idade; e Carlos Alberto em 2016 de infarto, com 72 anos de idade -, são muitos os casos de

${ }^{46}$ BARTHES. A câmara clara, p. 142.

47 BARTHES. A câmara clara, p. 142. Seria preciso lembrar, no entanto, que para Barthes (diferentemente do que para Kracauer), apesar de sua base fotográfica, o cinema tenderia a elidir esta presença da morte, porque dissolvida de algum modo no fluxo de imagens que capta a atenção, sem um intervalo ou espaço, sempre em direção à seguinte: "[...] no cinema, sem dúvida, sempre há referente fotográfico, mas esse referente desliza, não reivindica em favor da sua realidade, não declara sua antiga existência; não se agarra a mim: não é um espectro. Como o mundo real, o mundo fílmico é sustentado pela presunção de "que a experiência continuará a fluir no mesmo estilo constitutivo' [...]." (BARTHES. A câmara clara, p. 133-134). 
problemas mais ou menos graves de saúde (como mais recentemente os de Pelé), sendo também visível e em alguns casos mais dramática a deterioração da forma física, com o inchaço de todo o corpo (e perda da agilidade), o enrugamento da pele e o embranquecimento ou perda dos cabelos, além de todas as possíveis e diferenciadas dificuldades para encontrar uma atividade profissional satisfatória depois de esgotado o prazo da rápida carreira de jogador (com também todos os graves problemas econômicos e/ou psíquicos que disso podem resultar).

De qualquer modo, este conjunto de seis jogos da campanha vitoriosa da Seleção Brasileira na Copa de 1970 não poderia - é óbvio - ser pensado literal ou propriamente como uma biografia de qualquer um dos jogadores titulares que jogaram os seis jogos (como Tostão, Jairzinho ou Pelé, por exemplo), nem mesmo uma biografia esportiva ou futebolística, pois todos eles tiveram carreiras bem mais cheias e complexas envolvendo todos os campeonatos disputados por seus times profissionais (ou mesmo em categorias inferiores), e ainda muito menos uma biografia integral, que envolveria muitos outros aspectos da vida a partir de uma idade muito tenra e/ou posterior ao término da carreira de jogador, tal como já foi diversamente narrado em alguns documentários famosos (por exemplo, Garrincha alegria do povo de Joaquim Pedro de Andrade, Isto é Pelé de Luiz Carlos Barreto e Eduardo Escorel, ou Tostão fera de ouro de Paulo Laender e Maurício Gomes Leite) ou em biografias como a de Garrincha por Ruy Castro (Estrela solitária), ou a de Rivelino por Maurício Noriega (Rivellino), ou as inúmeras de Pelé, ou ainda - possibilidade bem mais rara - a(s) autobiografia(s) de um jogador que se tornou um bem reconhecido cronista esportivo da imprensa escrita, como Tostão (Lembranças, opiniões, reflexões sobre futebol, de 1997, e Tempos vividos, sonhados e perdidos, de 2016, que inclusive usei com proveito neste artigo).

O que o material documental cinematográfico dos vídeo-tapes destas seis partidas vitoriosas condensa (naquilo que poderia ser pensado também como uma espécie de compacto esportivo-existencial de exceção) é apenas um dos momentos mais privilegiados (ou, na grande maioria dos casos, o mais) das carreiras de vários grandes jogadores de futebol brasileiros, mas um momento largo em que eles, jovens e no auge de sua potência, como seres humanos mortais jogando uma de suas maiores chances (numa carreira bem breve e coincidentemente numa vida 
muito breve, ou seja: numa superposição intensiva de uma certa urgência: "ars brevis atque vita brevis", parodiando aqui o ditado), estavam imersos e inteiros, carregando cada qual consigo toda a sua história de vida (ainda que não diretamente manifesta), e podendo assim ser considerado também, e por excelência, biográfico. ${ }^{48}$

E, enfim, para concluir, seria preciso também considerar que, embora na posição modesta e passiva de um mero (mas apaixonado) espectador, este material fílmico documental destes seis vídeo-tapes (e, especialmente, da semifinal contra o Uruguai) permitia a mim - que havia visto as partidas transmitidas ao vivo pela televisão, ainda criança, com nove anos de idade - uma rememoração (com várias correções, precisões e acréscimos), 50 anos ou um inteiro meio século depois, não só da campanha vitoriosa da Seleção Brasileira nesta Copa do Mundo de 1970, mas também de todo um contexto social e histórico que havia se transformado muito e complexamente, tornando possível também, por toda uma vida dedicada à literatura (à filosofia e às ciências sociais) e amadoristicamente ao futebol (como um lazer muito especial, incluindo a prática até os 52 anos de idade), este meu relato-ensaio retrospectivo, que tem assim um óbvio caráter autobiográfico, inclusive em sua indisfarçada identificação com a habilidade única e excepcional (e maneira inteligente de jogar) do então maior jogador (o Tostão) do Cruzeiro, time de Belo Horizonte, minha cidade, ${ }^{49}$ de que eu fui um torcedor afortunado nos agora longínquos anos de 1960 e 1970, o que não só explica bem, como também explicita, sem retirar-me enquanto sujeito de todo o processo investigativo deste ensaio, a razão da escolha do objeto mesmo desta pesquisa,

\footnotetext{
${ }^{48}$ Curiosamente, em uma nota na introdução ao capítulo 2, "Basic Concepts", do livro Theory of Film, de que eu falava há pouco, Kracauer lembra, na esteira de Georges Sadoul (em L'invention du cinéma), que os nomes dados primeiramente ao filme indicavam uma afinidade ou com o "movimento" (como "kinetoscope", "kinetograph" ou "cinematógrafo") ou com a "vida" (como "vitascope", "vitagraph", "bioscope" ou "biograph", itálicos meus), tornando possível neste último exemplo a asserção etimológica literal do filme ou do cinema como "uma descrição" (por desenho ou pintura, gráphein, mas no seu caso pela fotografia, que é ainda mais precisa e exata) da "vida" (bíos), ou seja: do filme como literal e etimologicamente uma "biografia" de quem é documentado ou registrado em movimento pela câmera (cf. KRACAUER. Theory of Film, p. 28, nota de pé de página).

${ }^{49} \mathrm{E}$ desde muito tempo também a do Tostão (ou Eduardo Gonçalves de Andrade), com quem, por sinal, às vezes me encontro por acaso passeando na rua ou em algum bar ou restaurante no fim de semana, fazendo questão de saudá-lo com alguma reverência, mas sem forçar muito uma aproximação (pois sei que ele é tímido e reservado), apenas para indicar que o estou reconhecendo, tal como uma única vez lhe disse, como um grande craque do futebol e um dos mais inteligentes cronistas da mídia impressa e digital brasileira.
} 
corroborando de um modo bem chão e nada irônico a proposição hoje já bem conhecida de Ricardo Piglia de que "a crítica é a forma moderna da autobiografia". ${ }^{50}$

\section{REFERÊNCIAS}

BARTHES, Roland. A câmara clara: nota sobre a fotografia. Tradução de Júlio Castañon Guimarães. Rio de Janeiro: Nova Fronteira, 1984.

BENJAMIN, Walter. Pequena história da fotografia. In: BENJAMIN, Walter. Obras escolhidas vol. 1, Magia e técnica, arte e política. Tradução de Sérgio Paulo Rouanet. São Paulo: Brasiliense, 1985, p. 91-107.

BENVENISTE, Émile. Expression indo-européenne de l'éternité. Boulletin de la Société de Linguistique de Paris, Paris, v. 38, n. 1, p. 103-112, 1937.

BORGES, Jorge Luis. Funes, o memorioso. In: Ficções. Tradução de Carlos Nejar. In: BORGES, Jorge Luis. Obras completas, volume I (1923-1949). São Paulo: Editora Globo, 2000, 1ª edição: 1998, p. 539-546.

BORGES, Jorge Luis. O jardim de veredas que se bifurcam. In: Ficções. Tradução de Carlos Nejar. In: BORGES, Jorge Luis. Obras completas, volume I (1923-1949). São Paulo: Editora Globo, 2000, $1^{a}$ edição: 1998, p. 524-533.

CLODOALDO. Eu deixei a Itália quase que nocauteada para que nós pudéssemos fazer o gol. In: Favorita e no auge, seleção brasileira goleia e fatura a Jules Rimet. Folha de São Paulo. São Paulo, 21/06/2020, Série "O Tri de 70", Esporte. Disponível em: https://bit.ly/3tKn9ZH. Acesso em: 18 jul. 2020.

DILCHER, Roman. Chapter VII: The Divine Game. In: DILCHER, Roman. Studies in Heraclitus. Hildesheim: Olms, 1995, p. 145-157.

FRIEDLÄNDER, Paul. Lachende Götter. Die Antike, Berlin, v. 10, p. 209-226, 1934.

GÉRSON. Como é que você vai admitir que o Pelé jogue 45 minutos mal? In: Fantasma do Maracanazo aparece, mas Brasil reage e vai à final. Folha de São Paulo. São Paulo, 17/06/2020, Série "O Tri de 70", Esporte. Disponível em: https://bit.ly/3lxsdO9. Acesso em: 18 jul. 2020.

GUEZ, Olivier. Éloge de l'esquive. Paris: Bernard Grasset, 2014.

HOMERO. Ilíada. Tradução, introdução e notas de Christian Werner. São Paulo: Ubu Editora/SESI-ŞP Editora, 2018.

KRACAUER, Siegfried. Theory of Film: The Redemption of Physical Reality. London/New York: Oxford University Press, 1960.

50 PIGLIA. Formas breves, p. 139, tradução minha. Curiosamente, eu poderia também subscrever, pelas várias leituras e vídeos que a escrita deste relato-ensaio me demandou, o conjunto do parágrafo que esta frase de Piglia apenas introduz: "La crítica es la forma moderna de la autobiografía. Uno escribe su vida cuando cree escribir sus lecturas. ¿No es a la inversa del Quijote? El crítico es aquel que encuentra su vida en el interior de los textos que lee." (PIGLIA. Formas breves, p. 139). 
MARCOVICH, Miroslav. Heraclitus: Greek Text with a Short Commentary. Sankt Augustin: Academia Verlag, 2001.

PIGLIA, Ricardo. Epílogo. In: PIGLIA, Ricardo. Formas breves. Buenos Aires: Mondadori, 2014 [2000], p. 139-140.

RENNÓ ASSUNÇÃO, Teodoro. Breve nota sobre o tempo trágico no futebol. Letras Clássicas, Faculdade de Letras da Universidade de São Paulo, São Paulo, n. 12, p. 259-262, dez. 2008.

RODRIGUES, Sérgio. O drible. São Paulo: Companhia das Letras, 2013.

TORRES, Carlos Alberto. Fui com tudo, cheguei na passada certa, com a certeza de que iria fazer o gol. In: Favorita e no auge, seleção brasileira goleia e fatura a Jules Rimet. Folha de São Paulo. São Paulo, 21 jun. 2020, Série "O Tri de 70", Esporte. Disponível em: https://bit.ly/3ly9Ybc. Acesso em: 18 jul. 2020.

TOSTÃO. Foi o dia em que eu vi o Zagalo mais bravo na minha vida, ele ficou possesso. In: Fantasma do Maracanazo aparece, mas Brasil reage e vai à final. Folha de São Paulo. São Paulo, 17/06/2020, Série "O Tri de 70", Esporte. Disponível em: https://bit.ly/3r35FWl. Acesso em: 18 jul. 2020.

TOSTÃO. Na folga podia ir a festinhas, tomar uma cervejinha ou ir pra igreja rezar. In: Bastidores da Copa: relatos divertidos e curiosos de quem esteve lá. Folha de São Paulo. São Paulo, 21/06/2020, Série "O Tri de 70", Esporte. Disponível em: https://bit.ly/3eXLB5F. Acesso em: 18 jul. 2020.

TOSTÃO. Tempos vividos, sonhados e perdidos: um olhar sobre o futebol. São Paulo: Companhia das Letras, 2016.

TOSTÃO. Tostão: "Fuimos revolucionarios". El País. Madrid, 21/06/2020, 50 Aniversario de la final del Mundial de México, Deportes. Disponível em: https://bit.ly/39hXQqb. Acesso em: 22 nov. de 2020.

TOUSSAINT, Jean-Philippe. La Mélancolie de Zidane. Paris: Les Éditions de Minuit, 2006. 